\title{
DCEP Regimen
}

National Cancer Institute

\section{Source}

National Cancer Institute. DCEP Regimen. NCI Thesaurus. Code C137681.

A chemotherapy regimen consisting of dexamethasone, cyclophosphamide, etoposide, and cisplatin that may be used as a salvage regimen for relapsed and/or refractory plasma cell myeloma and/or as a mobilization regimen, followed by granulocyte colonystimulating factor (G-CSF), for peripheral blood stem cell (PBSC) collection in plasma cell myeloma. 